\title{
Development of tourist potential in the regions of the south of Russia
}

\author{
Vladimir Victorovich Kurchenkov \\ Volgograd State University, \\ Institute of Management and Regional Economy \\ Volgograd, Russia \\ kurchenkov@volsu.ru
}

\author{
Olga Vladimirovna Fetisova \\ Volgograd State University, \\ Institute of Management and Regional Economy \\ Volgograd, Russia \\ fetissova@volsu.ru
}

\author{
Yuliya Mikhaylovna Azmina \\ Volgograd State University, \\ Institute of Management and Regional Economy \\ Volgograd, Russia \\ azmina80@volsu.ru
}

\begin{abstract}
In the article the authors reveal the features of the regional tourist complex development in modern conditions. They also determine the directions for implementing the potential of the regional tourist services market. The article describes the multiplicative dependence for analyzing the interaction of primary and secondary sectors of the regional tourist services market. The authors reveal the main groups of efficiency indicators, and they study the degree of their relevance for evaluating the inbound tourism potential in the region. They also make the calculations of relative indicators reflecting the dynamics of incomes from inbound, outbound and domestic tourism relative to the total amount of income from tourism activities in the region for the reporting period, as a rule, for one calendar year. Based on these indicators, the regions of the Southern Federal District are classified according to the level of their tourist force of attraction. The reasons for the low tourist force of attraction of Volgograd region in comparison with other regions of the Southern Federal District are determined.
\end{abstract}

Keywords - tourism, domestic tourism, inbound and outbound tourism, tourist services, tourist services market, tourist force of attraction of the region, regional tourist complex, efficiency of the regional tourist complex, tourist cluster

\section{INTRODUCTION}

The development of the tourist services market in the regions is an important goal for the Russian economy development in the short term. Globalization of the world economy, intensification of competition between the tourist industry enterprises require high efficiency from regional tourist complexes. Considering that the increase in the intensity of domestic tourist flows is associated not only with the active work of tourist firms, but also with the development of transport and information infrastructure, the construction of new hotels and restaurants, it is necessary to implement a comprehensive approach to developing the basic elements of the regional tourist complex $[4 ; 8]$.

The experience of foreign countries proves that the development of regional tourist complexes is an important factor for increasing the competitiveness of the tourist industry throughout the country $[8,9]$. Thanks to the integrated approach to developing the regional tourist services market, many regions of our country have become leaders in attracting tourists from other regions and from abroad over the last decades.

For working out the integrated approach to developing the regional tourist services market, it is necessary to have a system for evaluating the regional tourist complex efficiency in the short term and in the long term. This system should take into account the incomes not only from tourist activities, but also the incomes that are earned in adjoining sectors of tourism [3].

Indeed, tourist activities can become a significant source of incomes also for regional budgets. These incomes can be formed, first of all, from the expenses of tourists from other countries and regions, and also as a result of the increase in the domestic tourism indicators. According to this fact, it is not entirely correct to calculate only those expenses that tourists spend directly on the organizers of tours. Being for a long time in one region, tourists use goods and services of local enterprises, go by regional kinds transport and use transport infrastructure facilities. These expenses can be related to secondary costs, which should be taken into account while calculating the regional tourism efficiency.

\section{The Methodology of Evaluating the Tourist} FORCE OF ATTRACTION OF THE REGION AND THE EFFICIENCY OF TOURIST ACTIVITIES.

As a rule, the secondary or derivative costs of tourists include the costs for transport services, purchase of goods and services of local enterprises, current service, information and communication services, insurance, banking services, etc. Consequently, the growth of the tourist flow in the region contributes to the increase in incomes both in primary sector (at the enterprises of the tourist industry) and in the secondary sector (at the enterprises of related industries or related activities). On the one hand, it helps to increase the employment of the region's population in these sectors by 
creating new jobs. On the other hand, it results in the increase in the incomes of several industries and, accordingly, in the deductions, which are in the form of taxes, to the regional budgets.

At the same time, there is a multiplicative dependence between the growth of incomes in primary and secondary sectors of the regional tourist services market. It means that with the increase in the tourist flow in the region and, consequently, with the increase in the costs for the tour operator, the costs in the secondary sector also grow, but not proportionally, in accordance with the effect of a multiplier (an accelerator) (Fig. 1).

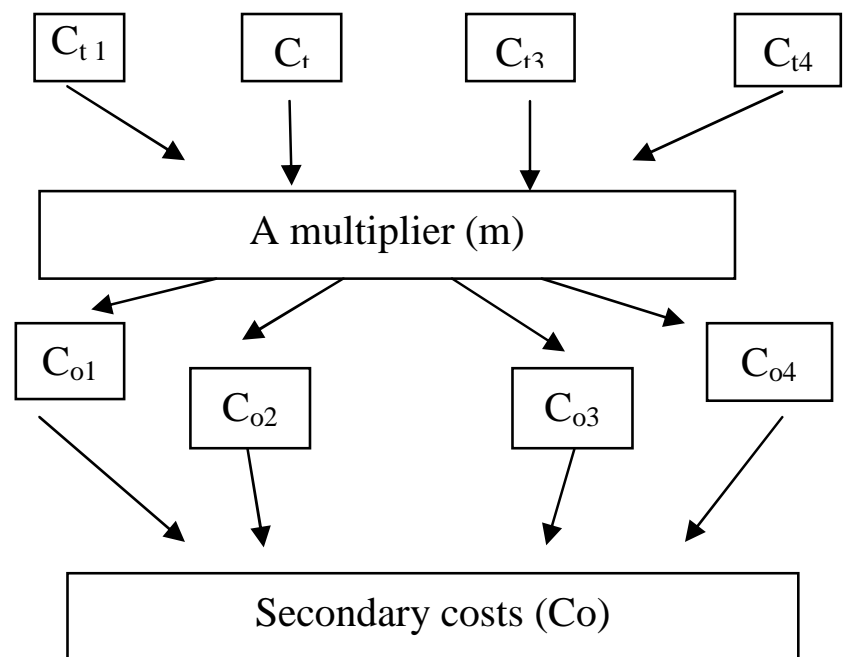

Figure 1. The Multiplicative Dependence between the Initial and Secondary Costs of Tourists in the Region

Thus, as shown in figure 1 , it is necessary to distinguish two levels of indicators for evaluating the amount of costs which deal with the beginning of active work of tourist firms in the region. The first level includes traditional indicators of costs directly for the services of the tour operator, as well as the costs for collective accommodation and meals for tourists visiting the region without the intermediation of travel companies (i.e. independently). The second level includes the indicators which reflect other accompanying costs of tourists for goods and services within the region.

According to this fact, the total amount of revenues from tourist activities in the region should be calculated with the help of the following formula.

$$
C_{s}=\sum C_{t}+\sum C_{o}+\sum P r_{o}
$$

where:

$\mathrm{C}_{\mathrm{t}}$ - the quantity of received money from the costs for tourist services from the tour operator;

$\mathrm{C}_{\mathrm{o}}$ - the quantity of received money from the tourists costs for the services of collective accommodation and meals without the intermediation of the tour operator;

$\mathrm{Pr}_{\mathrm{o}}$ - the quantity of received money from the costs for buying goods by tourists in the regional consumer market and also for transport, banking, insurance services and others;
$\mathrm{C}_{\mathrm{s}}$ - the total amount of the population costs on the tourist services market, including secondary costs.

In this case, according to the traditional approach in the economic theory [1] the value of the multiplier must be determined proceeding from the incremental costs of the primary and secondary sectors of the regional tourist services market over a particular period of time, (usually one calendar year). Consequently, the multiplier will be equal to:

\section{$\mathbf{m}=\left(\Delta \sum \mathbf{P r}_{\downarrow} \mathbf{0}\right) /\left(\Delta \Sigma \mathbf{C}_{\downarrow} \mathbf{t}+\Delta \Sigma \mathbf{C}_{\downarrow} \mathbf{0}\right)$}

(2);

where:

$\Delta \sum \mathrm{C}_{\mathrm{t}}-$ the increase in total costs for the tourist services of the tour;

$\Delta \sum \mathrm{C}_{\mathrm{o}}$ - the increase in total costs for the services of collective accommodation and meals without the intermediation of the tour operator;

$\Delta \sum \operatorname{Pr}_{\mathrm{o}}$ - the increase in total costs of tourists on the regional consumer market.

Knowing the approximate value of the multiplier for a typical region, we can calculate the total amount of population costs in the primary and secondary sectors of the regional tourist services market:

where:

$$
\Delta \mathrm{C}_{\mathrm{s}}=\mathrm{m} \Delta \sum \mathrm{C}_{\mathrm{t}}+\Delta \sum \mathrm{Ct}
$$

$\Delta \mathrm{C}_{\mathrm{s}}$ - the total increase in the population costs on the tourist services market, including secondary costs.

The value of this indicator is important for evaluating the efficiency of the regional tourist complex because as noted above, secondary costs are quite difficult to determine statistically, as it is difficult to isolate them from the total amount of costs in the regional market.

Thus, provided that such consumption indicators are not taken into account in the official statistics, in order to obtain the data it is necessary to carry out a questionnaire survey of tourists who have visited the region during the reporting period, for example, one current year.

\section{THE RESUlts OF Evaluating THE TOURIST ForCE OF ATTRACTION OF THE REGIONS AND INCOMES FROM TOURIST ACTIVITIES}

According to the rank of the tourist force of attraction, Volgograd region is in the second group on the basis of this criterion. It takes the 27 th position, and has 70 points out of 100 [2]. The main criteria for evaluating the tourist force of attraction are: the level of the hotel business and infrastructure development; the importance of the tourist industry in the region's economy; popularity of the region among the tourists who come for a few days; the popularity of the region among foreigners; tourist uniqueness; ecological "health" of the region; crime situation; interest in the region as a place of rest on the Internet; promotion of the region's tourism potential in the information space. 
From the above criteria, the main criterion for the region`s tourist force of attraction is the profitability of the tourist industry and of the region hospitality. This profitability is in turn characterized by the following indicators: the incomes of the collective accommodation facilities; the volume of paid tourist services for the population; the turnover of public catering.

However, as we have already marked, these profitability indicators, which are provided by official statistics, do not fully reflect the total amount of profit from tourist activities in the period under review [6]. It is so because these indicators do not take into account secondary incomes. Therefore, on the basis of the above methodology, it is necessary to analyze the tourist activities efficiency taking into account the primary and secondary incomes of Volgograd Region, that are earned from tourist activities, and also their ratio.

According to the data of the Analytical Agency "TurStat", Volgograd region is considered to be a low-cost regional center of Russia's regions, popular for travelling in the fall of 2017 [7]. In particular, Volgograd was in the list "Top-10 budgetary cities in the regions of Russia", popular with tourists, where the budget was from 2 to 2.5 thousand roubles per day per one tourist, along with such cities as Barnaul, Voronezh, Krasnodar, Volgograd, Smolensk, Kemerovo, Orel, Chelyabinsk, Bryansk and Izhevsk. The daily budget of the trip included the cost of living in a hotel or an apartment for 2 persons, lunch in a cafe and visiting the city museum in September 2017. The average period of tourist's being in the region is 3 days. Thus, the initial costs per one tourist (budget variant) can be from 6 to 8 thousand roubles per person.

As for the secondary costs, which include additional excursion programs, transportation services, purchase of goods on the regional consumer market and visiting restaurants, they are unfortunately not included in the statistical reporting and rating system. These costs can be taken into account only empirically, on the basis of a survey and questioning of tourists. According to it, we have conducted a survey of tourists visiting the region. As a result of it the average secondary expenses corresponding to the budget variant accounted for from 2 to 6 thousand roubles. And in this case the average value of the multiplier will be from 0.4 to 0.6 .

Taking into account that more than 500 thousand tourists ${ }^{1}$ visit Volgograd region every year, the volume of primary incomes is 4 billion roubles a year, and the volume of secondary incomes is 2.1 billion roubles. The total income from tourist activities in the region, without the revenues from outbound and domestic tourism, will be 6.1 billion roubles.

1 According to some data [2; 7], in 2017 the tourist flow was 927 thousand people a year. However, the evaluation of this indicator was made according to the frequency of using collective accommodation places. At the same time, it should be noted that not all people visiting our region come here for the purpose of tourism. Here it is necessary to take into account both their business trips and participation in scientific conferences and youth forums.
This kind of figure does not fully correspond to the data of the official statistics. It should also be noted that according to the general level of income from tourist activities, Volgograd Region has lower levels of this income in comparison with other regions of the Southern Federal District. The general indicators of primary and secondary incomes from tourist activities, as well as the average value of the multiplier of the Southern Federal District regions are presented in Table 1.

Table 1.

The Places of the Southern Federal District Regions According to the Sum of Primary and Secondary Incomes from Tourist Activities

\begin{tabular}{|c|c|c|c|}
\hline $\begin{array}{c}\text { The Southern } \\
\text { Federal District } \\
\text { regions }\end{array}$ & $\begin{array}{c}\text { The Initial } \\
\text { Costs per Day, } \\
\text { in thousand } \\
\text { roubles }\end{array}$ & $\begin{array}{c}\text { The Secondary } \\
\text { Costs per Day, } \\
\text { in thousand } \\
\text { roubles }\end{array}$ & $\begin{array}{c}\text { The Value of } \\
\text { the Multiplier }\end{array}$ \\
\hline $\begin{array}{c}\text { Krasnodar } \\
\text { region }\end{array}$ & 2,8 & 2,1 & 0,75 \\
\hline Rostov region & 2,7 & 1,6 & 0,6 \\
\hline $\begin{array}{c}\text { Volgograd } \\
\text { region }\end{array}$ & 2,5 & 1,5 & 0,6 \\
\hline $\begin{array}{c}\text { Astrakhan } \\
\text { Region }\end{array}$ & 2,4 & 1,7 & 0,7 \\
\hline $\begin{array}{c}\text { Republic of } \\
\text { Kalmykia }\end{array}$ & 1,8 & 1,1 & 0,7 \\
\hline $\begin{array}{c}\text { Republic of } \\
\text { Adygeya }\end{array}$ & 1,7 & 1,2 & 0,6 \\
\hline
\end{tabular}

The source: it is made by the authors.

As Table 1 shows, the average multiplier value is $0.6-0.7$ for the Southern

Federal District regions. It should be stressed once again that we analyze a budgetary visit in this case. This visit includes accommodation for 2 persons and meals. Knowing these values, as well as the average number of tourists per year, one can calculate the total income that the region receives from inbound tourism. However, one should take into account that the average period of a tourist's stay on the territory of a particular region is different. In particular, in Volgograd and Rostov regions it is 3 days, in Astrakhan region it is 4 days, in the Republic of Kalmykia and Adygeya it is 2 days, in Krasnodar region it is 5-6 days.

\section{CONCLUSION}

Thus, the development of the tourist services market is an important source of income for the region. The high level of the tourist force of attraction becomes a condition for developing small business, transport and information infrastructure, creating additional jobs in the service sector, and ultimately for the revenue increase of regional budgets [5].

An important factor in analyzing the dynamics of increased income from tourist activities in the region is the accounting of primary and secondary incomes, which are formed in different proportions depending on the region, the level of its social and economic development, the development of the tourist industry, geographical location and climatic conditions. 
Primary incomes include revenues of the tour operator, incomes from collective accommodation of tourists, catering. Secondary incomes are made from incomes for transport services, purchase of goods and services of local enterprises, current service, information and communication services, insurance, banking services, etc. At the same time, secondary incomes are not always adequately reflected in the official statistics. And primary and secondary incomes from the tourist activities in the region are in multiplicative dependence.

This carried out analysis of incomes according to the proposed methodology has shown the difference in the total amount of incomes from tourist activities in the region, in contrast to the statistical data, and the change in the position of the region rating in terms of the tourist force of attraction. We have made the ranking of the Southern Federal District regions on the basis of the tourist force of attraction criterion and the value of the dynamics of aggregate revenues from tourist activities; we have also defined the place of Volgograd region in the rating characterizing the average efficiency and profitability of tourist activities in the region.

\section{REFERENCES:}

1. Keynes, J. K. The General Theory of Employment, Interest and Money / The Anthology of Economic Classics in 2 volumes / Edited by I. A. Stolyarov, - 1993, Moscow: Econov, Volume II, P.486.

2. National Tourist Rating - 2017. - [Electronic source]. URL: http://russia-rating.ru/info/13018.html. [Accessed: 18/12/2017].

3. Rubtsova, N.V. Testing the Methodology for Evaluating the Socio-Economic Efficiency of the Region's Tourist Activities (on the Example of the Baikal Region) // Business. Education. Right. The Bulletin of the Volgograd Institute of Business. 2015. 1 (30). p.110-116.

4. The Strategy for the Tourism Development in the Russian Federation for the Period until 2020 (the Decree of the Government of the Russian Federation of May 31, 2014 No. 941-r). [Electronic source]. - Access mode: http://government.ru/media/files/41d4e55c9b1d8bca7b6a.pdf.

5. Fedorets, L. N. Evaluating the Efficiency of the Tourist Cluster / Fedorets L. N. // Vector of Science of TSU. Economics and Management. - 2011. - №1 (4). - p. 42-45.

6. Kurchenkov V.V., Fetisova O.V., Matina E.S. MultiCriteria Assessment of the Development Potential of the Tourism and Recreational Cluster of the Volgograd Region// Journal of Environmental Management and Tourism, Volume VI, Issue 1(11), Summer 2015, ASERS Publishing, p. 69-79.

7. Fetisova O.V., Kurchenkov V.V., Matina E.S. Improvement Options for Transactional Factors of Tourism and Recreation Cluster in Volgograd Region // Journal of Environment Management and Tourism, 2016, Volume VII, Issue 3(15), - p. 493 - 504.

8. Nepal, S.K. Tourism as a Key to Sustainable Mountain Development: the Nepalese Himalayas in Retrospect, Unasylva 208, - 2002, - Vol. 53, p. 38-46.
9. Tourism and mountains. A Practical Guide to Managing the Environmental and Social Impacts of Mountain Tours. United Nations Environment Programme, 2007. Available from: http://www.eldis.org/go /home\&id=43904\&type=Document\#. VMON7EesU3s [Accessed: 01/2017]. 